\title{
Perencanaan Jaringan In-Building Coverage Di Gedung X
}

\author{
Sinka Wilyanti, S.T., M.T. ${ }^{1)}$, Mauludi Manfaluthy, S.T., M.T. ${ }^{2)} \&$ Drama Wicaksono ${ }^{3)}$ \\ Institut Teknologi dan Kesehatan Jakarta \\ JL. Jatiwaringin Raya No. 278, Pondok Gede 17411, Jakarta \\ Website: https://itkj.ac.id, E-mail: Sinka@itkj.ac.id, mauludi@itkj.ac.id,drama@itkj.ac.id
}

\begin{abstract}
Abstrak - Saat ini, kebutuhan akan komunikasi bergerak semakin berkembang pesat, dengan bertambahnya pengguna telepon selular dan juga bertambahnya gedung-gedung pencakar langit dengan kontruksi yang menghambat sinyal seluler untuk penetrasi ke dalam gedung tersebut. Hal ini menyebabkan komunikasi di dalam gedung bertingkat menjadi terganggu, untuk itu dibutuhkan sebuah solusi untuk mengatasi permasalahan tersebut. In-Building Coverage akan menjadi solusi untuk permasalahan ini, dengan menggunakan model path loss slope yang telah banyak digunakan dalam perencanaan jaringan In-Building Coverage. Antena akan didistribusikan ke setiap lantai gedung, sehingga sinyal yang dipancarkan oleh antenna dapat menjangkau lebih dari 95\% area gedung tersebut atau sesuai dengan kesepakatan antara pihak terkait. Sinyal yang dipancarkan oleh antena tentunya dipengaruhi oleh link budget tiap antena. Daya penerimaan antenna akan diukur dengan telepon genggam yang diinstal perangkat lunak Tems Pocket juga dengan metode walktest menggunakan telepon genggam dan laptop yang diinstal perangkat lunak Tems Investigation untuk melihat apakah sinyal yang dipancarkan sudah memenuhi standar dari operator seluler. Dari hasil pengujian di lapangan, tidak terjadi gangguan dalam komunikasi seluler di dalam gedung. Hasil pengujian di lantai Semi Basement didapat nilai RSCP rata-rata -48 dBm, di lantai 6 didapat nilai $R S C P$ rata-rata $-52 \mathrm{dBm}$ dan di lantai 12 didapat nilai $R S C P$ rata-rata $-45 \mathrm{dBm}$.
\end{abstract}

Kata kunci: Jaringan IBC, Link Budget, In-Building Coverage.

\begin{abstract}
Abstrak - At present, the need for mobile communication is growing rapidly, with the increase in cellular phone users and also the increase of skyscrapers with construction that inhibits cellular signals for penetration into the building. This causes disruption in communication in high rise buildings, for that we need a solution to overcome these problems. In-Building Coverage will be a solution to this problem, using the path loss slope model that has been widely used in planning for inbuilding coverage. Antennas will be distributed to each floor of the building, so that the signal emitted by the antenna can reach more than $95 \%$ of the building area or in accordance with an agreement between the parties concerned. The signal emitted by the antenna is certainly influenced by the link budget of each antenna. The antenna reception power will be measured by a mobile phone installed with Tems Pocket software as well as a walktest method using a mobile phone and a laptop installed with Tems Investigation software to see whether the signal emitted meets the standards of the cellular operator. From the results of tests in the field, there was no disruption in cellular communication in the building. Test results on the Semi Basement floor obtained an average RSCP value of $-48 \mathrm{dBm}$, on the 6th floor an average RSCP value of $-52 \mathrm{dBm}$ was obtained and on the 12th floor an average RSCP value of $-45 \mathrm{dBm}$ was obtained.
\end{abstract}

Kata kunci: Jaringan IBC, Link Budget, In-Building Coverage.

\section{Pendahuluan}

Saat ini kebutuhan akan komunikasi semakin berkembang pesat, dengan bertambahnya pengguna telepon selular setiap harinya dan juga bertambahnya gedung-gedung pencakar langit dengan kontruksi yang menyulitkan sinyal

Dipresentasikan pada Tanggal 30 November 2019 Copyright (C) 2019 FT - UHAMKA. - All rights reserved seluler untuk penetrasi ke dalam gedung tersebut. Hal ini menyebabkan komunikasi di dalam gedung bertingkat menjadi terganggu, untuk itu dibutuhkan sebuah solusi untuk mengatasi permasalahan tersebut. 
Dengan In-Building Coverage yang menyediakan jaringan penguat sinyal di dalam gedung-gedung tersebut. In-Building Coverage mendistribusikan banyak antenna ke setiap lantai gedung bertingkat. Hal ini dapat mendukung mobilitas para pengguna seluler yang penggunaannya semakin meningkat. In-Building Coverage juga dapat mengatasi permasalahan buruk nya sinyal di dalam lift maupun basement.

\section{$2 \quad$ Landasan Teori}

Komunikasi seluler dikembangkan untuk mengatasi masalah keterbatasan spektrum frekuensi dan kapasitas yang kecil dari komunikasi nirkabel konvensional serta untuk mendukung mobillitas pengguna yang semakin tinggi [1].

Konsep seluler pada jaringan telepon seluler membagi daerah menjadi sel-sel dengan masing-masing sel diberikan daya transmit yang relatif kecil [2]. Konsep selular menggunakan variabel level daya yang rendah, memperbolehkan ukuran sel disesuaikan dengan kepadatan pelanggan dan permintaan pada suatu area. Sebagaimana perkembangan populasi, sel dapat ditambahkan untuk mengakomodir pertumbuhan tersebut.

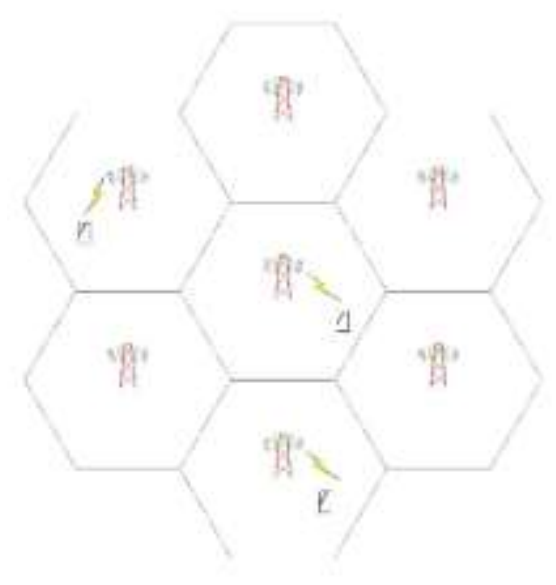

Gambar 1 Desain pembagian sel ideal

In-Building Coverage merupakan suatu sistem yang diterapkan dalam gedung untuk mendukung sistem luar gedung dalam memenuhi layanan seluler [3].

\subsection{Material}

Mengetahui jenis dan kegunaan material yang akan digunakan untuk perancangan IBC sangat diperlukan. Material yang umum digunakan memiliki nilai redaman yang berbeda, tergantung jenis dan frekuensi yang akan digunakan.

\section{1) Antenna}

Antenna Omnidirectional biasa disebut juga antenna nondirectional yaitu jenis antenna yang mempunyai pola pancaran ke segala arah atau jenis antenna yang tidak memiliki pola pancaran ke satu arah tertentu. Antenna ini sering digunakan dalam hubungan komunikasi nirkabel jarak pendek, yang menghubungkan point to multi-point atau yang menghubungkan satu point pemancar ke banyak point penerima. Sehingga antenna ini dapat diletakan di tengah - tengah sebagai pemancar dan penerima pada posisi sekeliling antenna. Antenna ini memiliki sudut pancaran radiasi yang besar yaitu $360^{\circ}$ atau satu putaran penuh pada sekelilingnya [4].

Gain antenna omni yang banyak digunakan untuk instalasi jaringan $I B C$ saat ini adalah $5 \mathrm{dBm}$.

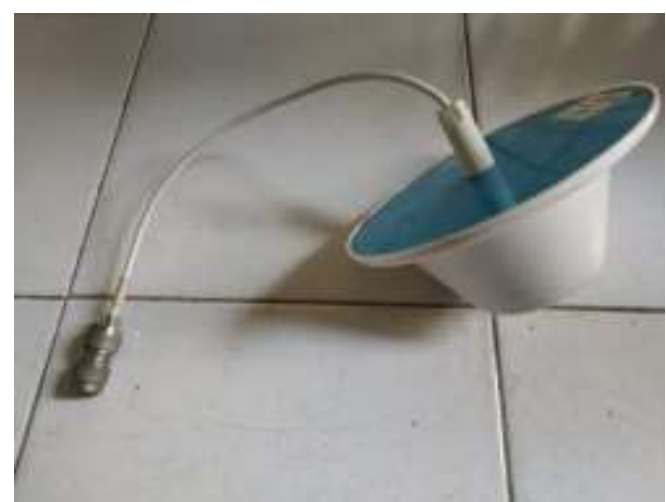

Gambar 2 Antenna omni

2) Feeder Cable

Feeder Cable adalah kabel yang digunakan untuk menyalurkan gelombang. Redaman feeder cable sangat dipengaruhi oleh luas penampang dan frekuensi yang digunakan. Berikut ini adalah tabel redaman feeder cable.

Tabel 1 Redaman feeder cable

\begin{tabular}{|l|c|c|}
\hline \multirow{2}{*}{\multicolumn{2}{|c|}{ Jenis }} & \multicolumn{2}{c|}{ Redaman $(\mathrm{dB} / \mathrm{m})$} \\
\cline { 2 - 3 } & $1800 \mathrm{MHz}$ & $2100 \mathrm{MHz}$ \\
\hline Feeder Cable 1/2" & 0.0996 & 0.109 \\
\hline Feeder Cable 7/8" & 0.0563 & 0.0615 \\
\hline Feeder Cable 11/4" & 0.0415 & 0.0455 \\
\hline
\end{tabular}

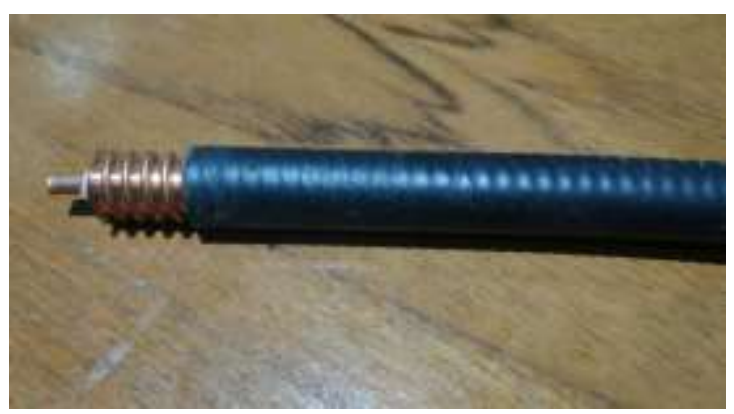

Gambar 3 Feeder Cable 
3) Power Splitter

Power Splitter adalah suatu komponen untuk membagi sinyal $R F$ menjadi dua, tiga atau lebih. Seperti hal nya feeder cable, tiap Splitter memiliki redaman yang berbeda.

Tabel 2 Redaman Power Splitter

\begin{tabular}{|l|c|}
\hline \multicolumn{1}{|c|}{ Power Splitter } & Redaman $(\mathrm{dB})$ \\
\hline Splitter 2-Way & 3.3 \\
\hline Splitter 3-Way & 5.1 \\
\hline Splitter 4-Way & 6.3 \\
\hline
\end{tabular}

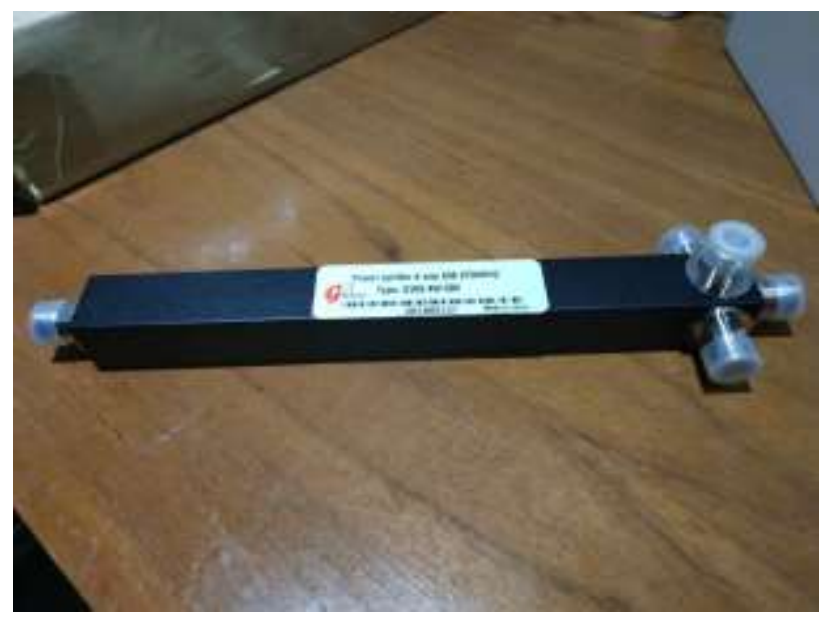

4) Connector

Gambar 4 Power Splitter

Connector dipasang pada ujung tiap feeder cable agar dapat dihubungkan ke komponen-komponen lain nya. Connector yang dipergunakan dalam perencanaan $I B C$ biasanya memiliki 2 jenis, yaitu Din dan $N$. Nilai redaman tiap connector adalah $0.15 \mathrm{~dB}$.

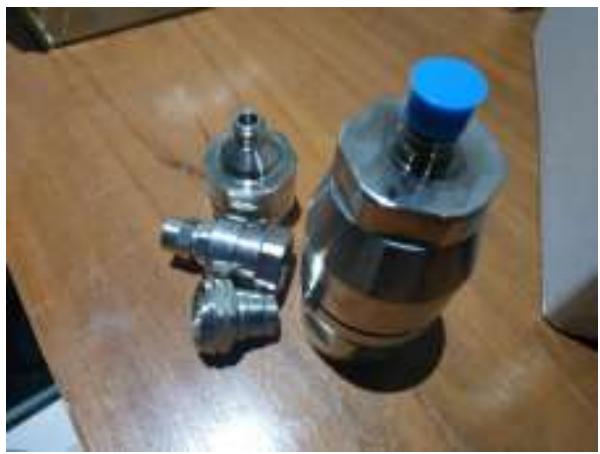

Gambar 5 Connector

5) Jumper

Jumper digunakan untuk menyambungkan komponen satu dengan lain nya. Loss jumper dipengaruhi oleh panjang jumper tersebut.

Tabel 3 Redaman Jumper

\begin{tabular}{|c|c|}
\hline Jumper & Redaman $(\mathrm{dB})$ \\
\hline Jumper 0.3 meter & 0.16 \\
\hline Jumper 1 meter & 0.24 \\
\hline Jumper 3 meter & 0.46 \\
\hline Jumper 5 meter & 0.68 \\
\hline
\end{tabular}

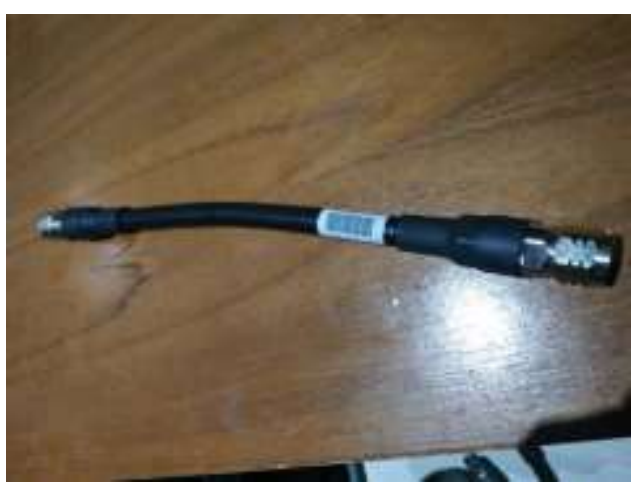

Gambar 6 Jumper Cable N Male - N Male $30 \mathrm{~cm}$

6) Combiner

Combiner adalah alat yang digunakan untuk menggabungkan dua atau lebih frekuensi yang berbeda [5].

Tabel 4 Redaman Combiner

\begin{tabular}{|l|c|}
\hline \multicolumn{1}{|c|}{ Combiner } & Redaman $(\mathrm{dB})$ \\
\hline Hybrid Coupler & 3 \\
\hline Wideband Combiner & 6.4 \\
\hline
\end{tabular}

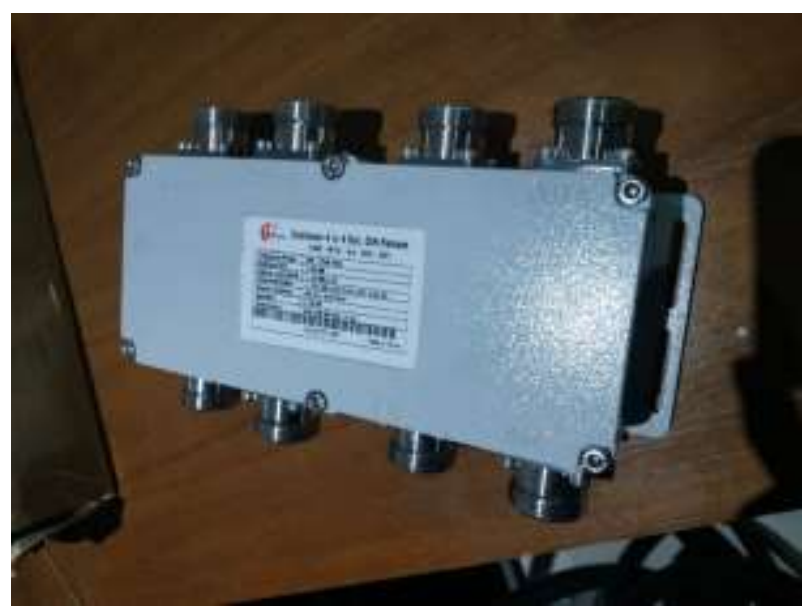

Gambar 7 Wideband Combiner 698-2700 MHz (4in, 4Out) Din Female Port

\subsection{Link Budget}

Perhitungan link budget dibutuhkan dalam perencanaan InBuilding Coverage untuk dapat mengetahui seberapa luas jangkauan dari sebuah antenna pada frekuensi tertentu.

1) Effective Isotropic Radiated Power

Effective Isotropic Radiated Power (EIRP) adalah penjumlahan antara daya pancar dengan gain (penguatan) antenna dari pemancar [6]. EIRP dapat dihitung dengan persamaan [7];

$E I R P=P_{T X}+G_{T X}-L_{T X}$

$P_{T X}:$ Daya pancar $(\mathrm{dBm})$

$L_{T X}$ : Rugi-rugi daya $(\mathrm{dB})$

$G_{T X}$ : Penguatan antenna $(\mathrm{dBi})$ 
2) Free Space Loss

Free Space Loss (FSL) adalah rugi-rugi daya yang dipancarkan oleh antenna. Free Space loss sangat dipengaruhi oleh jarak antara pemancar dan penerima, frekuensi dan keadaan yang dilaluinya. Nilai Free Space Loss dapat dihitung dengan persamaan [8];

$$
F S L=32.44+20(\log f)+20(\log d)
$$

$$
\begin{aligned}
& f: \text { Frekuensi }(\mathrm{MHz}) \\
& d: \text { Jarak }(\mathrm{km})
\end{aligned}
$$

3) Path Loss

Path loss $(P L)$ adalah redaman yang terjadi ketika sinyal melewati media udara dari antenna pemancar ke antenna penerima dalam jarak tertentu. Besaran path loss dapat dihitung dengan persamaan [9];

$$
\text { Path Loss }=\text { FSL at } 1 M+P L S * \log (d)
$$

FSL at $1 \mathrm{M}$ : Free Space Loss pada jarak 1 meter

\section{PLS : Koefisien In Building}

d : Jarak (m)

4) Allowable Path Loss

Allowable Path Loss (APL) adalah nilai maksimal path loss yang diperbolehkan. $A P L$ dapat dihitung dengan persamaan [9];

$$
\begin{aligned}
& \text { APL= EIRP-Rx Min } \\
& \text { EIRP : EIRP }(\mathrm{dBm})
\end{aligned}
$$

Rx Min : Nilai minimum penerimaan yang ditentukan oleh perusahaan atau Operator Seluler (dBm)

5) Antenna Service Radius Antenna Service Radius adalah perhitungan perkiraan cakupan antenna. Hal ini untuk mengetahui seberapa jauh perkiraan antenna dapat menjangkau area tersebut. Persamaan untuk mengetahui antenna radius adalah [9];

\section{APL : Allowable Pathloss}

FSL at $1 \mathrm{~m}$ : Free Space Loss pada jarak 1 meter

PLS : Koefisien Path Loss Slope, disesuaikan dengan keadaan di lapangan

6) Receive Signal Level

Receive Signal Level adalah daya pancar yang diterima oleh receiver. $R S L$ dapat dihitung dengan persamaan [10]:

$$
R S L=E I R P-\text { Path Loss }+G_{R X}-L_{R X}
$$

\subsection{Model PLS}

Model yang banyak digunakan untuk menghitung $I B C$ adalah path loss slope model (PLS). PLS ini memiliki atenuasi yang berbeda untuk berbagai jenis lingkungan dan frekuensi. Model umum didasarkan pada analisis dari sejumlah besar sampel pengukuran di berbagai jenis lingkungan [11] [12].
Tabel 5 PLS

\begin{tabular}{|c|l|c|}
\hline No & \multicolumn{1}{|c|}{ Type Of Environtment } & PLS \\
\hline 1 & Open Environtmert & 30.1 \\
\hline 2 & Moderately Open Environtmert & 32 \\
\hline 3 & Slightly Dense Environtmert & 3.1 \\
\hline 4 & Moderately Dense Environtmert & 34.8 \\
\hline 5 & Dense Environtmert & 38.1 \\
\hline
\end{tabular}

Keterangan;

- Open Environtment: Parkir, Basement, Convention Center

- Moderately Open Environtmen: Pabrik, Gudang, Bandara

- Slightly Dense Environtmert: Mall

- Moderately dense environment: Perkantoran

- Dense environment: Rumah sakit

\subsection{Walktest}

Walktest adalah suatu metode pengukuran sinyal dengan menggunakan perangkat keras komputer jinjing, telepon selular atau tablet yang telah terpasang perangkat lunak yang dapat menampilkan nilai sinyal suatu operator selular [7].

Hasil pengukuran biasanya direkam untuk dapat dipergunakan untuk keperluan tertentu, misalnya untuk mengetahui area yang sinyalnya belum maksimal.

\subsection{Spotcheck}

Spotcheck merupakan suatu metode pengukuran kekuatan receive signal level di bawah antenna. Spotcheck dilakukan dengan menggunakan telepon selular yang sudah terpasang aplikasi yang dapat menampilkan nilai receive signal level sesuai standar operator selular.

\section{Metodologi Penelitian}

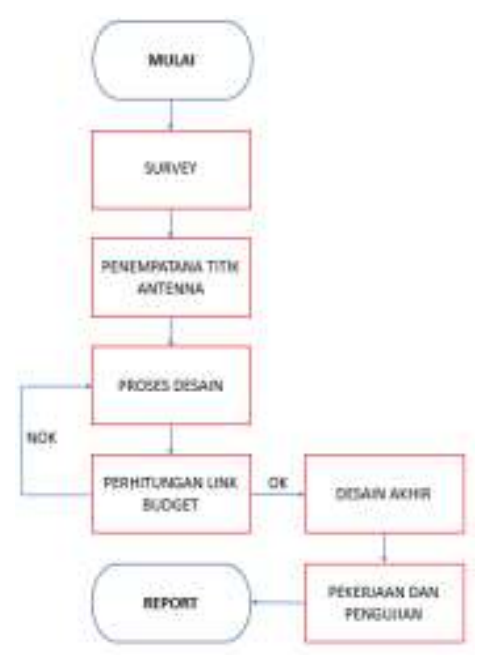

Gambar 8 Flowchart 
Pada dasarnya perencanaan $I B C$ ini dikerjakan dalam lima tahap, yaitu;

\section{1) Site Survey}

Site survey dilakukan untuk dapat mengetahui kondisi di lapangan, luas area yang akan dipasang, akses, penempatan BTS, penempatan antenna [13].

2) Perkiraan Penempatan Titik Antenna Antenna ditempatkan di titik-titik tertentu di dalam gedung yang dapat menjangkau area dalam Gedung.

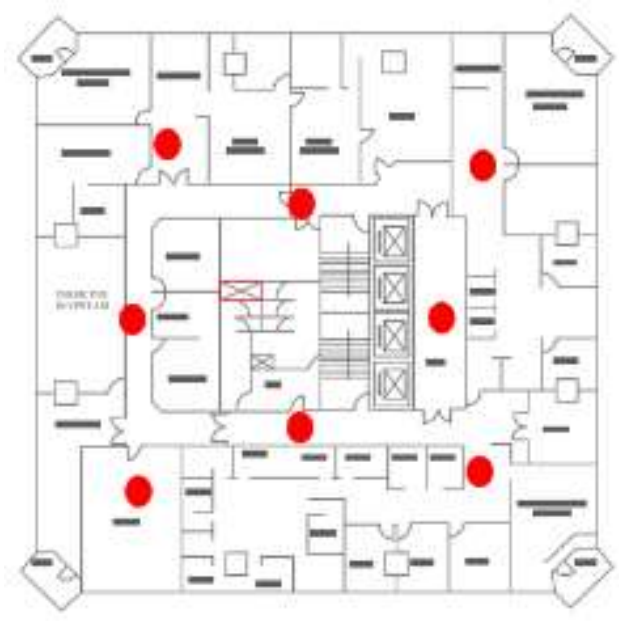

Gambar 9 Perkiraan penempatan titik antenna

3) Membuat Draft Design

Setelah informasi yang dibutuhkan telah dilengkapi pada saat site survey, selanjutnya adalah membuat draft design berdasarkan coverage commitment [14] [15].

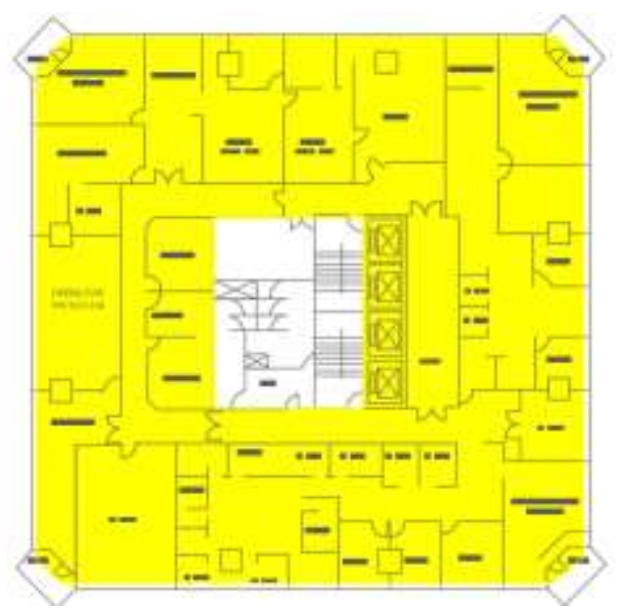

Gambar 10 Coverage Commitment

Desain yang diperlukan dalam pembuatan draft ini adalah;

\section{Cable Route \& Antenna Location}

Yaitu gambar yang menenjelaskan rute untuk feeder cable dan penempatan antenna omni di area gedung tersebut.

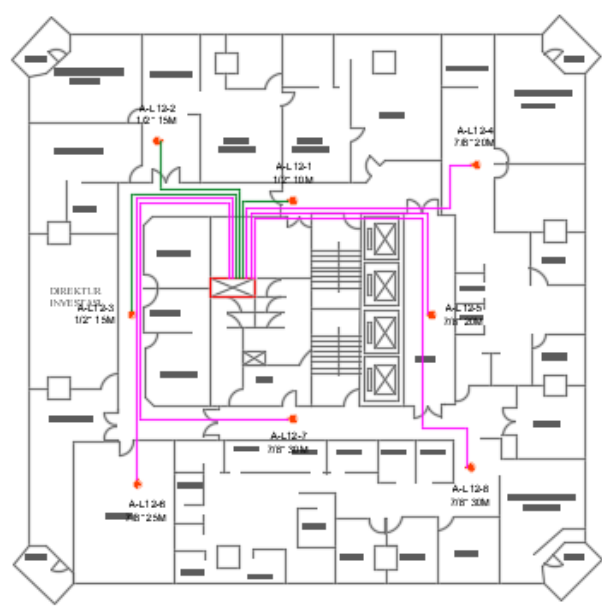

Gambar 11 Cable Route \& Antenna Location

Yang harus diperhatikan untuk penempatan antenna ini adalah lokasi atau titik pemasangan di lapangan.

\section{Schematic Diagram}

Schematic diagram adalah desain yang memperlihatkan susunan material atau komponen yang digunakan. Schematic diagram sangat penting untuk menentukan EIRP dan path loss dari sebuah antenna.

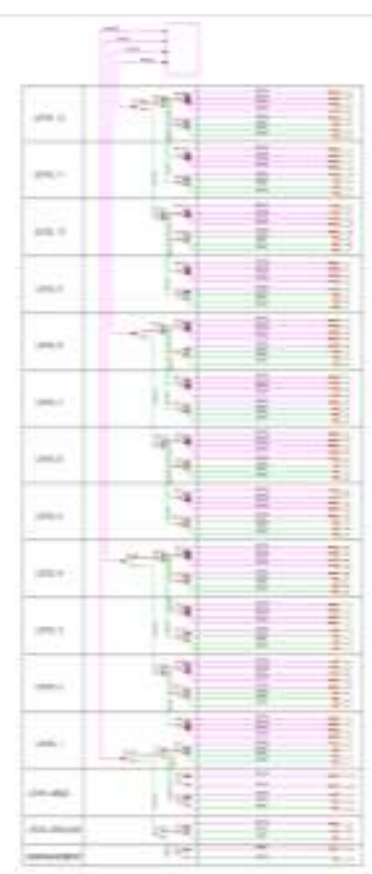

Gambar 12 Schematic Diagram

4) Kalkulasi Link Budget

Menghitung link budget agar dapat diperkirakan radius service antenna.

\section{Menghitung EIRP}

Berikut ini adalah daftar material yang dipergunakan untuk antenna 1 di lantai 12. 
Tabel 6 Loss material Antenna 1 di lantai 12

\begin{tabular}{|c|l|c|c|c|c|c|}
\hline No & \multicolumn{1}{|c|}{ Material } & Type & Loss & Qty & Unit & Total \\
\hline 1 & $\begin{array}{l}\text { Jumper BTS to } \\
\text { Combiner }\end{array}$ & 5 meter & 0.68 & 1 & $\mathrm{pc}$ & 0.68 \\
\hline 2 & $\begin{array}{l}\text { Wideband } \\
\text { Combiner }\end{array}$ & $\begin{array}{c}4 \text { in }-4 \\
\text { out }\end{array}$ & 6.4 & 1 & $\mathrm{pc}$ & 6.4 \\
\hline 3 & Jumper & 1 meter & 0.24 & 2 & $\mathrm{pcs}$ & 0.48 \\
\hline 4 & Jumper & $\begin{array}{c}0.3 \\
\text { meter }\end{array}$ & 0.16 & 2 & $\mathrm{pcs}$ & 0.32 \\
\hline 5 & Connector & $\mathrm{N}$ & 0.15 & 4 & $\mathrm{pcs}$ & 0.6 \\
\hline 6 & Splitter & 2 Way & 3.3 & 1 & $\mathrm{pc}$ & 3.3 \\
\hline 7 & Splitter & 4 Way & 6.4 & 2 & $\mathrm{pcs}$ & 12.8 \\
\hline 8 & $\begin{array}{l}\text { Feeder } \\
\text { (Backbone) }\end{array}$ & $7 / 8 "$ & 0.062 & 50 & $\mathrm{~m}$ & 3.075 \\
\hline 9 & Feeder Antenna & $1 / 2 "$ & 0.109 & 10 & $\mathrm{~m}$ & 1.09 \\
\hline & & & \multicolumn{2}{|c|}{ Total Loss } & & 28.745 \\
\hline
\end{tabular}

A-L12-1 = Tx Power - Loss + Gain Antenna

$=33 \mathrm{dBm}-28.745+5$

$=9.255 \mathrm{dBm}$

\section{Menghitung Free Space Loss}

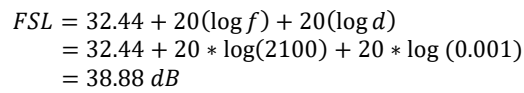

\section{Menghitung Allowable Path Loss}

\section{Menghitung Antenna Service Radius}

Setelah semua nilai yang dibutuhkan didapat, dapat dilanjutkan dengan menghitung antenna service radius.

$$
\begin{aligned}
A-L 12-1 & =10^{\frac{A P L-F S L \text { at } 1 \mathrm{~m}}{P L S}} \\
& =10^{\frac{89.26-38.88}{34.8}} \\
& =28.02 \text { meter }
\end{aligned}
$$

5) Desain Akhir

Jika perhitungan link budget antenna dapat memenuhi kriteria, maka dibuat desain akhirnya sesuai dengan daya pancar yang telah dihitung.

\section{Hasil dan Pembahasan}

\subsection{Perhitungan Received Signal Level}

Received signal level dihitung untuk dapat dibandingkan dengan pengukuran di lapangan.

$$
\begin{aligned}
\text { FSL } 2.1 G H z= & 32.44+20 * \log f+20 * \log d \\
= & 32.44+20 * \log (2100)+20 \\
& * \log (0.001)=38.88 d B
\end{aligned}
$$

Path Loss 2.1GHz pada jarak 5 meter

$$
=F S L+P L S * \log d
$$

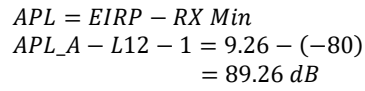

$$
=38.88+34.8 * \log (5)=63.2 d B
$$$$
R S L=E I R P-\text { Path Loss }+G_{R X}-L_{R X}
$$

RSL $A-L 12-1=E I R P-$ Path Loss $+G_{R X}-L_{R X}$

$$
\begin{aligned}
& =9.26-63.2+0-0 \\
& =-55.18 \mathrm{dBm}
\end{aligned}
$$

\subsection{Pengukuran Signal Level}

Pengukuran dilakukan dengan menggunakan alat bernama tems pocket yang memungkinkan untuk mengetahui besaran yang diterima oleh perangkat.

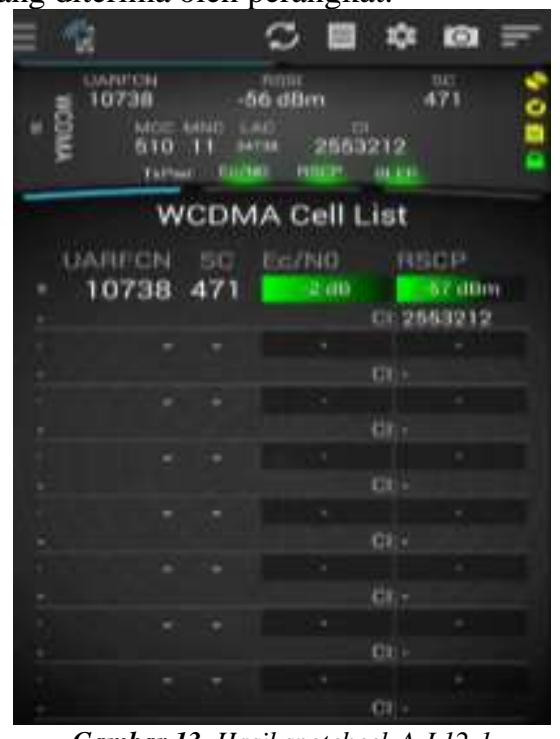

Gambar 13 Hasil spotcheck A-L12-1

Tabel 7 Perbandingan RSL

\begin{tabular}{|c|c|c|c|c|c|}
\hline \multirow{2}{*}{ No } & Nama & \multicolumn{4}{|c|}{ Received Signal Level at 5m } \\
\cline { 3 - 6 } & Antenna & Perhitungan & Pengukuran & Unit & Deviasi \\
\hline 1 & A-L12-8 & -55.18 & -65 & $\mathrm{dBm}$ & $15 \%$ \\
\hline 2 & $\mathrm{~A}-\mathrm{L} 12-7$ & -55.18 & -61 & $\mathrm{dBm}$ & $10 \%$ \\
\hline 3 & A-L12-6 & -54.88 & -58 & $\mathrm{dBm}$ & $5 \%$ \\
\hline 4 & A-L12-5 & -54.57 & -65 & $\mathrm{dBm}$ & $16 \%$ \\
\hline 5 & A-L12-4 & -54.57 & -58 & $\mathrm{dBm}$ & $6 \%$ \\
\hline 6 & A-L12-3 & -54.49 & -60 & $\mathrm{dBm}$ & $9 \%$ \\
\hline 7 & A-L12-2 & -54.49 & -59 & $\mathrm{dBm}$ & $8 \%$ \\
\hline 8 & A-L12-1 & -53.95 & -57 & $\mathrm{dBm}$ & $5 \%$ \\
\hline 9 & A-L6-8 & -57.64 & -68 & $\mathrm{dBm}$ & $15 \%$ \\
\hline 10 & A-L6-7 & -57.64 & -58 & $\mathrm{dBm}$ & $1 \%$ \\
\hline 11 & A-L6-6 & -57.34 & -60 & $\mathrm{dBm}$ & $4 \%$ \\
\hline 12 & A-L6-5 & -57.03 & -61 & $\mathrm{dBm}$ & $7 \%$ \\
\hline 13 & A-L6-4 & -57.03 & -69 & $\mathrm{dBm}$ & $17 \%$ \\
\hline 14 & A-L6-3 & -56.95 & -64 & $\mathrm{dBm}$ & $11 \%$ \\
\hline 15 & A-L6-2 & -56.95 & -58 & $\mathrm{dBm}$ & $2 \%$ \\
\hline 16 & A-L6-1 & -56.41 & -58 & $\mathrm{dBm}$ & $3 \%$ \\
\hline 17 & A-SB-2 & -53.97 & -57 & $\mathrm{dBm}$ & $5 \%$ \\
\hline 18 & A-SB-1 & -53.05 & -57 & $\mathrm{dBm}$ & $7 \%$ \\
\hline & & & Rata-Rata & $\mathbf{8 \%}$ \\
\hline
\end{tabular}




\subsection{Pengujian dengan metode Walktest}

Walktest dilakukan dengan menggunakan perangkat laptop yang telah terpasang perangkat lunak khusus yang disambungkan dengan tems pocket.

Pengujian dengan metode ini untuk mengetahui $R S L$ pada saat melakukan panggilan telepon dan kualitasnya.

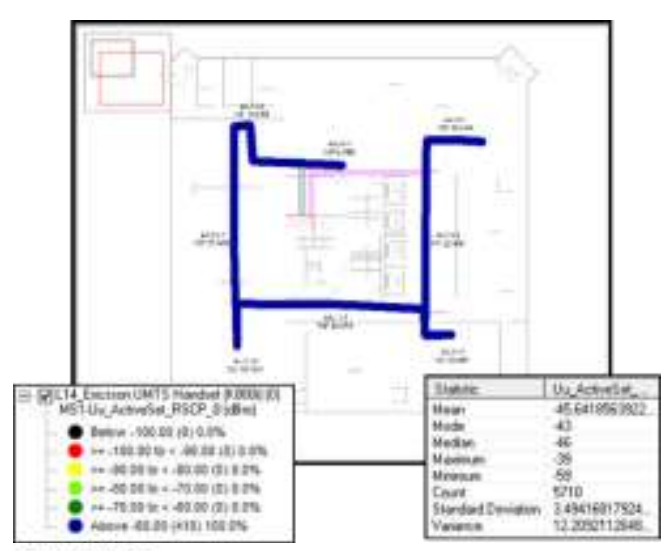

caus stanstic

- This report ahown all matime Plous, note that the drop call rate is band on succesaful calls onity
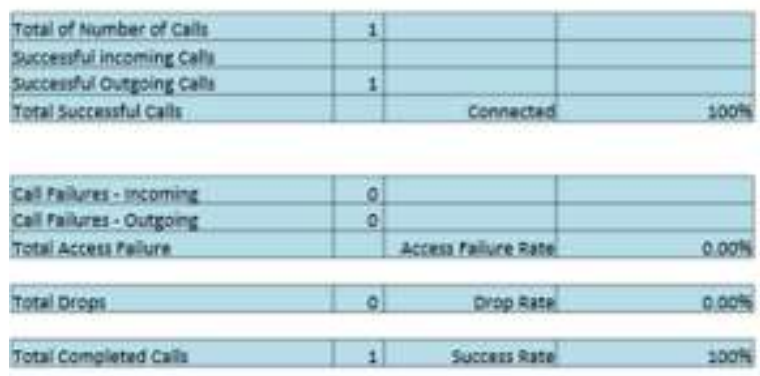

Gambar 14 Hasil Walktest di lantai 12

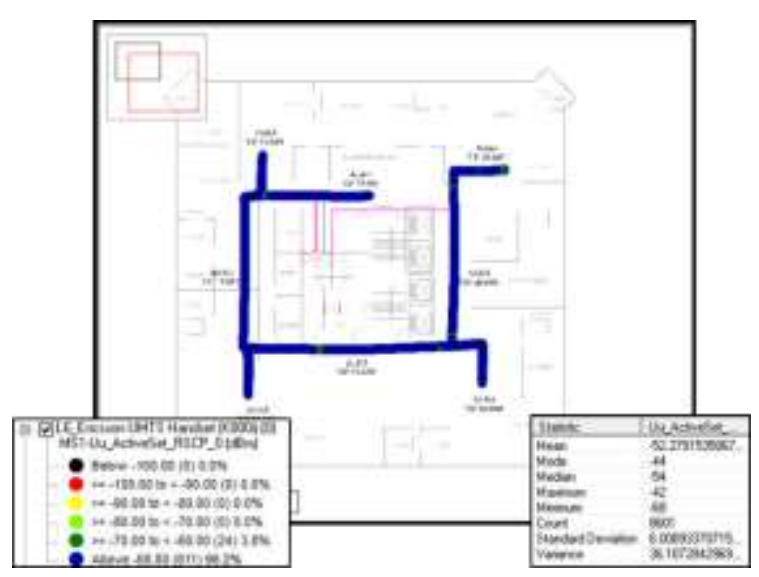

CALl STATISTIC

- This ragort shows all statistic. Please, note that the drop call rate is based on ruccessful calls only

\begin{tabular}{|l|l|l|l|}
\hline Total of Number of calts & 1 & & \\
\hline succestul incoming calls & & & \\
\hline succesdful outgoing calls & 1 & & \\
\hline Total Successtul cals & & connected & $100 \%$ \\
\hline
\end{tabular}

\begin{tabular}{|c|c|c|c|}
\hline call falures - Incoming & Q. & & \\
\hline call fabures - Outgoing & 0 & & \\
\hline Totat Access falure: & & Acstss failure rate & $0.00 \%$ \\
\hline
\end{tabular}

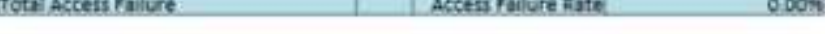

\begin{tabular}{|c|c|c|c|}
\hline Total Drops & 0 & Drop fate & $0,00 \%$ \\
\hline
\end{tabular}

\begin{tabular}{|c|c|c|}
\hline Total Compirted Calls. & 1 & Succers late \\
\hline
\end{tabular}

Gambar 15 Walktest di lantai 6

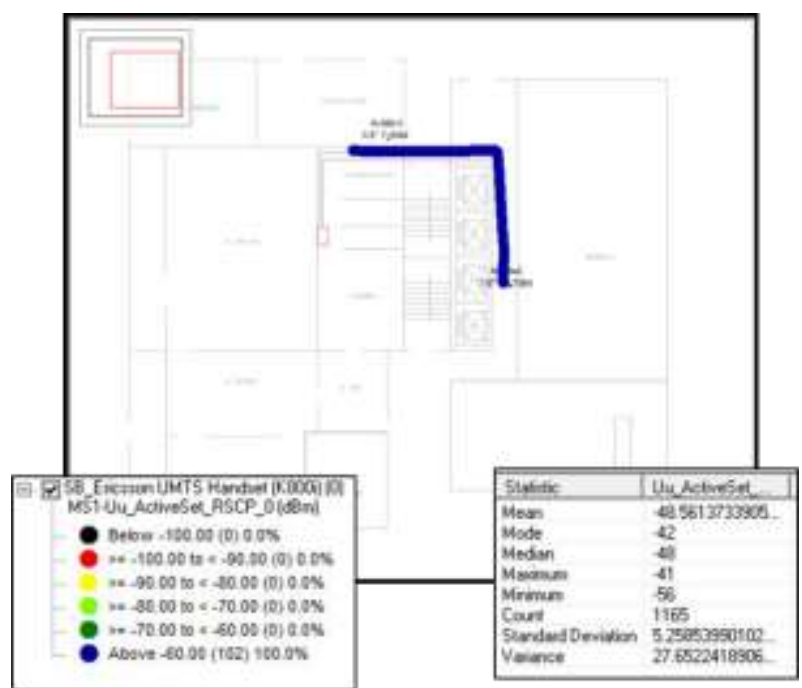

Caul statisne

- This report shows all sativec. phease, note thur the drog call rate is based on succestulul cals only
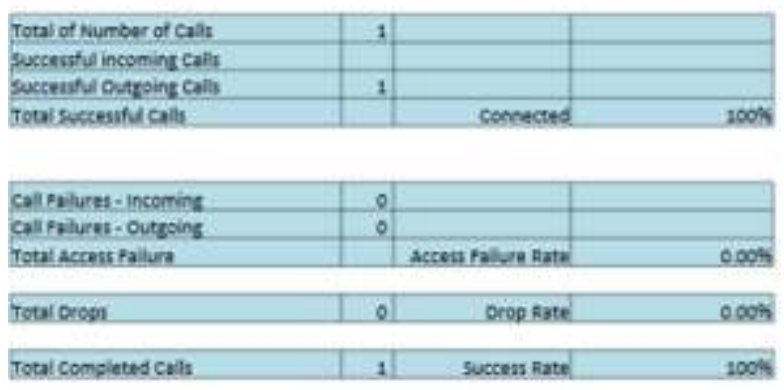

Gambar 16 Walktest di lantai Semi Basement

\section{Kesimpulan}

Hasil pengujian di lantai Semi Basement didapat nilai $R S C P$ rata-rata $-48 \mathrm{dBm}$, di lantai 6 didapat nilai $R S C P$ rata-rata $52 \mathrm{dBm}$ dan di lantai 12 didapat nilai $R S C P$ rata-rata -45 $\mathrm{dBm}$ (dedicate).

Sedangkan pada saat idle nilai $R S C P$ yang didapat rata-rata $-60.7 \mathrm{dBm}$ pada jarak 5 meter dari antenna. Terjadi penyimpangan sekitar $8 \%$ dari perhitungan awal yang nilai rata-ratanya adalah $-55.6 \mathrm{dBm}$. 


\section{Kepustakaan}

[1] M. G. Sakti, Y. S. Rohmah dan G. P. Fitrianto, "PERENCANAAN INDOOR BUILDING COVERAGE (IBC) JARINGAN LTE DI GEDUNG APARTEMEN SUITES @METRO,” e-Proceeding of Applied Science, vol. 4, pp. 2828-2837, 2018.

[2] G. Wibisono, U. K. Usman dan G. D. Hantoro, Konsep Teknologi Seluler, Bandung: Informatika Bandung, 2008.

[3] A. Hikmaturokhman, L. Berlianti dan W. Pamungkas, "Analisa Model Propagasi Cost 231 Multi Wall pada Perancangan Jaringan Indoor Femtocell HSDPA menggunakan Radiowave Propagation Simulator," Seminar Nasional Aplikasi Teknologi Informasi (SNATi) 2015, pp. E1-E9, 2015.

[4] M. Hanafi, P. Sedianinggsih dan F. Imansyah, "Analisa Perancangan Antena Omni Vertikal Sebagai Tranxceiver Penguat Router Wifi Dengan Frekuensi 2,4 GHz," Jurnal Teknik Elektro Universitas Tanjungpura, vol. I, pp. 1-7, 2017.

[5] Ardiansyah dan D. W. Astuti, "ANALISA PERFORMANSI RECEIVED TOTAL WIDEBAND POWER (RTWP) TERHADAP KUALITAS PERFORMANSI JARINGAN PADA JARINGAN WCDMA IBC TELKOMSEL," Jurnal Teknologi Elektro, vol. 7, pp. 84-94, 2016.

[6] D. M. M. Yudha, D. M. M. Yudha dan N. I. ER, "ANALISIS PARAMETER JARINGAN HSDPA KONDISI INDOOR DENGAN TEMS INVESTIGATION DAN G-NETTRACK PRO,” E-Journal SPEKTRUM, vol. 3, no. 1, pp. 40-46, 2016.

[7] A. D. Widowatie, L. D. M and A. Hariyadi, "OPTIMASI PENEMPATAN ELECTRONIC DATA CAPTURE (EDC) BERBASIS DRIVE TEST 3G DI GEDUNG PUSAT PERBELANJAAN," Jurnal JARTEL, vol. 6, no. 1, pp. 167-171, 2018.

[8] L. S. Arsasiwi, J. M. Bonatua, H. Mahmudah dan A. Wijayanti, "ANALISA PERHITUNGAN LINK BUDGET SISTEM KOMUNIKASI ANTAR ELABUHAN MENGGUNAKAN KANAL HF," Prosiding SENTIA, vol. 8, pp. D79-D84, 2016.
[9] M. Tolstrup, Indoor Radio Planning A Practical Guide for GSM DCS, UMTS and HSPA, Chichester: A John Wiley \& Sons, Ltd, 2008, p. 344

[10] F. Bacharuddin, S. Budiyanto and L. E. P. Siagian, "Analisa Link Budget Dalam Menentukan Titik Antena Pada Sistem DCS1800 Dan UMTS2100 Di Gedung IKEA Tanggerang," pp. 141-153, 2015.

[11] K. K. Pinem dan N. Mubarakah, "Analisis Link Budget Pada Pembangunan BTS RoofTop Cemara IV Sistem Telekomunikasi Seluler Berbasis GSM,” vol. 9, pp. 144-148, 2014.

[12] A. Hikmaturokhman, L. Berlianti dan W. Pamungkas, "Analisa Model Propagasi Cost 231 Multi Wall pada Perancangan Jaringan Indoor Femtocell HSDPA menggunakan Radiowave Propagation Simulator," Seminar Nasional Aplikasi Teknologi Informasi (SNATi) 2015, pp. E1-E9, 2015.

[13] Akmal dan Y. Rahayu, "Perancangan Jaringan Femtocell Pada Jaringan 3G Di Gedung C Fakultas Teknik Universitas Riau," Jom FTEKNIK, vol. 4, no. 2, pp. 1-11, 2017.

[14] H. Yuliana, A. Charisma and Sunubroto, "Perencanaan dan Simulasi Indoor Building Coverage (IBC) Pada Jaringan Long Term Evolution (LTE) menggunakan Radiowave Propagation Simulation (RPS)," Seminar Nasional Sains dan Teknologi 2018 , pp. 1-10, 2018.

[15] Triyanti dan Febrizal, "Perancangan Jaringan LTE (Long Term Evolution) Indoor di Gedung C Fakultas Teknik Universitas Riau," Jom FTEKNIK, vol. 4, no. 1, pp. 1-7, 2017. 